This is an Open Access article distributed under the terms of the $\underline{\text { Creative }}$ CommonsAttribution 4.0 International License which permits unrestricted noncommercial use, distribution, and reproduction in any medium, provided the original work is properly cited.

\title{
THE EFFECT OF TOUCH THERAPY ON NUTRITION STATUS AND THE DEVELOPMENT OF INFANTS
}

\author{
SITI INDATUL LAILI ${ }^{1}$, TRI RATNANINGSIH ${ }^{2}$, TRI PENI ${ }^{3}$ \\ Bina Sehat PPNI health science institute Mojokertoregency East Java Indonesia
}

Email correspondence: sitiindatullaili@yahoo.co.id

\section{ABSTRACT}

Infancy started from 0-12 months which was characterized by rapid growth and physical changes accompanied by changes in nutritional needs to optimize the growth and development of the baby by providing touch, motion, and other stimulation combinations. The research was purposed to know the effect of Touch Therapy on nutritional status and development on infants in Gayaman Village, Mojokerto Regency. The research design used one group pre-post test design. The population was infants in Gayaman Village, Mojokerto Regency, 70 respondents. The sample was 69 infants (0-18 months) in Gayaman Village, Mojokerto Regency, who were obtained by purposive sampling. Measuring instruments were used to assess nutritional status and Denver II forms to assess the progress. The research was done on July 28 to August 25, 2018. The statistical test used the Wilcoxon Signed Rank Test. The results showed that nutritional status before being given touch therapy was normal as many as $57(83 \%)$ respondents, and the development after being given touch therapy increased to $66(96 \%)$ respondents. The development before being given touch therapy was normal as many as 27 (39\%) respondents with $\rho=0.003$. This showed that there was an effect on touch therapy to their nutritional status. The nutritional status after being given a touch therapy increased to $57(83 \%)$ respondents with $\rho=0.008$. This showed that there was an effect of touch therapy on their development. Massaging was a fun way to help to strengthen the bond between mother and child. This was the key to baby's development.
Keywords

Touch

Therapy, Nutrition, Development 


\section{INTRODUCTION}

Infancy started from 0-12 months which is characterized by rapid growth and physical changes accompanied by changes in nutritional needs (Notoatmodjo, 2007). The stages of growth in infancy are divided into neonates with ages 0-28 days and postneonates with ages 29 days-12 months. The neonates are the first month of critical life because the baby will experience adaptation to the environment, changes in blood circulation, and the functioning of the organs, and in the post neonates, the baby will experience very rapid growth (Potter \& Perry, 2005).

To know the nutritional condition of the baby, knowledge of nutritional status is needed. Nutritional status is a measure of success in fulfilling nutrition for children which is indicated by the child's weight and height. Nutritional status is also defined as the health status obtained by the balance between need and nutrient input. Assessment of nutritional status is a measurement based on anthropometric and biochemical data and personal history.

Nutritional status in children, especially in infants, determines their next development. Development is the increasing of skill in the structure and functions of the body which is more complex in a regular predictable pattern, as a result of the maturation process, involving the process of differentiation of body cells, body tissues, organs and organ systems which develops in such a way that each of them can fulfill its function, including emotional development, intellectual and behavior as a result of interaction with the environment (Soetjiningsih, 1995).

Poor nutritional status in under-five years old can influence on physical, mental and thinking growth which will ultimately reduce work productivity. The prevalence of malnutrition under-fives is an indicator of the Millennium Development Goals (MDGs) that must be achieved in an area (district/ city) in 2015, namely the decline in the prevalence of malnourished children under five to 3.6 percent or underweight children under 15.5 percent (Nasional, 2015).

The results of the research (Chong, Wright, Goh, Meyer, \& Rao, 2018) Growth of children with food allergies in Singapore showed Eczema, IgE-mediated and mixed type allergies are associated with poorer growth rates in these children.

The results of the research (Gao, Jia, \& Huang, 2018) showed A total of 26 studies encompassing 2644 patients were included in this meta-analysis. It was shown that pediatric massage was significantly better than pharmacotherapy in treating acute diarrhea in children in terms of clinical effective rate $(n=2213, \mathrm{RR}=1.20$, 95\% CI: 1.14 to 1.27 ), clinical cure rate $(n=345, \mathrm{RR}=1.37,95 \%$ CI: 1.19 to 1.57$)$, and cure time $(n=513, \mathrm{MD}=-0.77,95 \%$ CI: -0.89 to -0.64$)$. However, the quality of evidence for this finding was low due to high risk of bias of the included studies.

According to RISKESDAS 2013, in Indonesia the number of infants aged zero to one year amounted to 4,665,025 with 2,396,024 male and 2,269,001 female. East Java Province has 574,308 infants with 293,487 male and 280,821 female, while Malang City has 6,024 infants.

According to the 2013 RISKESDAS, the nutritional status of Indonesian infants is still quite large with a prevalence of $5.7 \%$ in the category of malnutrition and $13.9 \%$ in the category less nourished. In East Java province, nutritional status based on body weight according to age with the prevalence of malnutrition was $4.9 \%$, and the prevalence of malnutrition 
was still quite large at $14.2 \%$ (Kesehatan \& Penelitian, 2014).

Baby's weight is one indicator in evaluating the baby's nutritional status. Apart from being influenced by internal factors such as nutritional intake, the baby's weight is also influenced by external factors such as stimuli. Stimulus can be in the form of touch therapy (Touch therapy). Touch therapy has been being practiced by rural and urban communities in Indonesia. Research on the effect of Touch therapy on increasing infant weight has been done both at Indonesia and abroad.

The research conducted by Hanifah Rahmania in Lampung in 2015 entitled The Effect of Touch on Weight Gaining results, Touch therapy can increase baby weight through the neuroendocrine mechanism (Hanifah, 2015).

The research conducted by Tri Sasmi Irva1 in Riau with the research title "the effect of touch therapy on infant body weight" obtained the results of the research based on the Wilcoxon test in the experimental group before and after giving touch therapy obtained a p-value of 0,000 (p $<0.05)$ which was meaningful and can increase the body weight, the increase in body weight is 700 grams during 2 weeks of touch (Irva, Hasanah, \& Woferst, 2014).

Stimulation plays a role in increasing growth hormone. Also, stimulation in the form of touch can improve the work of hormones and the digestive system. This causes nutrients to be absorbed properly so that optimal infant growth is achieved. Touch is a therapy that is carried out through mild to moderate touch. Touch is an art of health care that has been recognized by humans and is a treatment that was practiced since the beginning of human creation into the world, because the process is related to pregnancy and human birth. Humans experience a touch when the birth process is done which must leave the warm uterus and pass through a narrow birth canal which gives rise to traumatic experiences and anxiety. Touches and touches which performed immediately after birth will maintain a sense of security after being guaranteed the child's body contact.

Based on the phenomenon above, researchers will conduct research on Touch therapy. This research will prove the effect of Touch therapy on nutritional status and development of infants, to have optimal development, good nutritional status is needed. Good nutritional status can be obtained by external stimulation which is performed in touch (Touch therapy).

\section{MATERIAL AND METHODS}

This research is a comparative analytical research, with a pre-experimental design approach (one group pre-post test design). Data collection was carried out in one group by assessing the nutritional status and development of infants then the researchers provided education on touch therapy with lectures, video screenings, and touch therapy demonstrations. The respondents were asked to practice touch therapy after wards. Then the respondents touch therapy the baby at home every day for 15 minutes and within four weeks. At the end of week 4, researchers assessed the nutritional status and development of infants. The independent variable is the implementation of touch therapy. While the dependent variable in this research is nutritional status and development. The population in this research were all infants in Gayaman Village, Mojokerto Regency, 70 respondents. The sampling technique 
used purposive sampling. The sample of this research is 69 infants in Gayaman Village, Mojokerto Regency, with sample inclusion criteria, namely infants aged 0-18 months. This research was conducted in Gayaman Village, Mojokerto Regency from July 28 to August 25, 2018. Measuring instruments used by the scales to assess nutritional status and forms of Denver II to assess progress. Test statistics using the Wilcoxon Signed Rank Test.

\section{RESULT}

This research includes the characteristics of respondents, namely:

\section{GENERAL DATA}

The characteristic of respondents based on gender

Table 1 The Frequency Distribution Based On Gender In Gayaman Village Mojokerto Regency from July 28 to August 25, 2018.

\begin{tabular}{llll}
\hline No & Gender & $\begin{array}{l}\text { Frequency } \\
(\mathrm{F})\end{array}$ & $\begin{array}{l}\text { Prosentase } \\
(\%)\end{array}$ \\
\hline 1 & Male & 39 & 57 \\
2 & Female & 30 & 43 \\
\hline & Total & 69 & 100
\end{tabular}

Source: Primer Data

Based on table 1, it was known that most of the respondents were male 39 $(57 \%)$.

The characteristic of respondents based on age

Table 2 The Frequency Distribution Based On Age In Gayaman Village Mojokerto Regency from July 28 to August 25, 2018

\begin{tabular}{llll}
\hline No & Age (Month) & F & $\%$ \\
\hline 1 & $0-3$ & 9 & 13 \\
\hline
\end{tabular}

\begin{tabular}{llll}
\hline 2 & $4-6$ & 12 & 17 \\
3 & $7-9$ & 12 & 17 \\
4 & $10-12$ & 15 & 22 \\
5 & $13-18$ & 21 & 31 \\
\hline & Total & 69 & 100 \\
\hline
\end{tabular}

Source: Primer Data

Based on table 2 it was known that most of the respondents 21 (31\%) were 1318 months.

\section{Specific Data}

Table 3 The Frequency Distribution Of Nutritional Status In Gayaman Village Mojokerto Regency from July 28 to August 25, 2018.

\begin{tabular}{|c|c|c|c|c|c|}
\hline \multirow[t]{2}{*}{ No } & \multirow{2}{*}{$\begin{array}{l}\text { Nutritional } \\
\text { Status }\end{array}$} & \multicolumn{2}{|c|}{ Before } & \multicolumn{2}{|c|}{ After } \\
\hline & & $\mathrm{F}$ & $\%$ & F & $\%$ \\
\hline 1 & Very thin & 0 & 0 & 0 & 0 \\
\hline 2 & Thin & 0 & 0 & 0 & 0 \\
\hline 3 & Normal & 57 & 83 & 66 & 96 \\
\hline 4 & Fat & 12 & 17 & 3 & 4 \\
\hline & Total & 69 & 100 & 69 & 100 \\
\hline
\end{tabular}

Source: Primer Data

Based on table 3 it was known that the nutritional status of infants before being given touch was normal as many as 57 (83\%) respondents. And after being given touch increased to66 (96\%) respondents.

Based on table 3 it was known that $\rho=0.03$. This showed that there was an effect of infants touch on their nutritional status.

Table 4 The Frequency Distribution Of Infant's development In Gayaman Village Mojokerto Regency from July 28 to August 25, 2018. 


\begin{tabular}{|c|c|c|c|c|c|}
\hline \multirow[t]{2}{*}{ No } & \multirow{2}{*}{$\begin{array}{l}\text { The } \\
\text { Development }\end{array}$} & \multicolumn{2}{|c|}{ Before } & \multicolumn{2}{|c|}{ After } \\
\hline & & $\mathrm{F}$ & $\%$ & $\mathrm{~F}$ & $\%$ \\
\hline 1 & Normal & 27 & 39 & 57 & 83 \\
\hline \multirow[t]{2}{*}{2} & Suspect & 42 & 61 & 12 & 17 \\
\hline & Total & 69 & 100 & 69 & 100 \\
\hline$\rho_{\text {hitu }}$ & $0,008=$ dan $\alpha_{\text {tabel }}=0$ & & & & \\
\hline
\end{tabular}

Based on table 4 it was known that the development of infants before being given touch was normal as many as 27 (39\%) respondents. And after being given touch was increasing as many as $57(83 \%)$ respondents.

Based on table 4 it was known that $\rho=0.008$. This showed that there was an effect of infants touch on their development.

\section{DISCUSSION}

1. Identifying the nutritional status in Gayaman Village, Mojokerto Regency

Based on table 3 it was known that the nutritional status of infants before being given touch was normal as many as $57(83 \%)$ respondents, after being given touch increased becoming 66 (96\%) respondents. The research result showed there was an increasing of infant's nutritional status after being given touch for four weeks.

Touch stimulation is a form of stimulation combination, namely touch (tactile) and motion (kinesthetic) that can be done by parents. Basically, the purpose of touch therapy or touch stimulation is to optimize the growth, and development of the baby by providing touch stimulation, motion and other stimulation combinations. Touch stimulation is done in a pleasant and comfortable condition. The touch takes about 15 minutes, and should be given regularly.
There is no standard limit regarding the frequency of giving touch per day. However, parents should make touch stimulation as a routine and do it three times a day if possible. The technique for touch for a term baby and baby for fewer months is different.

The technique for term babies is quite varied and as much as possible covers all parts of the body. The order of the touch technique is intended so that no body parts are missed, but can be given not sequentially. This shows that routine baby touch and touch from parents or caregivers is a crucial factor for growth.

Body weight is the result of an increase or decrease of all tissues in the body, including bones, muscles, fat, body fluids and others. Body weight is used as the best indicator to determine the nutritional status and growth of the baby. Body weight is one of the most important anthropometric measures because it is used to check the health of children in all age groups. Because usually, children who suffer from certain infections will inhibit their growth and development. Infection during the baby's growth period is very dangerous because the disease in the baby's body will cause a decrease in appetite so that it can affect the baby's weight gain (Nursalam \& Dian, 2007).

Increased body weight indicates good nutritional status. Good nutritional status can be achieved if the body gets enough adequate nutrients, allowing physical growth to occur. With adequate nutrition, it can facilitate a balanced growth process for transporting oxygen and nutrients so that cells can grow to function normally. Increasing the child's weight in the first year of life can be happen if the child gets good nutrition, from babies born to the first six months of weight gain every 
week 140-200 grams. Baby's weight is becoming twice of the birth weight at the end of the first six months. While at the age of 6-12 months, weight gain every week ranges from 85-400 grams. Body weight will increase by three times of the birth weight at the end of the first year (Irva et al., 2014).

Factors that can affect the birth weight are internal environmental factors and external environments factors. The internal environment includes maternal age factors, birth distance, parity, hemoglobin levels, nutritional status of pregnant women, pregnancy examinations, diseases during pregnancy, while external environmental factors are environmental health, personal hygiene, work, education, maternal economic welfare (Rochjati, 2003).

Babies who are touchded have increased levels of absorption enzymes and insulin so that absorption of food juices gets better. As a result, the baby becomes hungry quickly and therefore suckles more often, so it increases milk production. Besides that, 15-minute touch therapy for six weeks in infants aged 1-3 months also increases alertness and reduced crying. This will be followed by an increase in body weight, improvement in psychological conditions, reduced levels of stress hormones, and increased serotonin levels (Utami, 2009).

Increased body weight indicates good nutritional status. Good nutritional status can be achieved if the body gets enough adequate nutrients, allowing physical growth to occur (Irva et al., 2014).

Regularly given touch by giving touch tactile (tactile) and motion (kinesthetic) carried out by parents will improve the baby's blood circulation, increase appetite which has an impact on increasing baby's weight. There is no standard limit regarding the frequency of giving touch per day. However, parents should make touch stimulation as a routine. Touch techniques for term infants and infants fewer months are different. Techniques for term infants are quite varied and as much as possible cover all parts of the body. The order of the touch technique is intended so that no body parts are passed but it can be given not sequentially. This shows that routine baby touch and touch from parents or caregivers is a crucial factor for growth.

2. Identifying the development in Gayaman Village, Mojokerto Regency

Based on table 4 it was known that the development of infants before being given touch was normal as many as 27 (39\%) respondents. And after being given touch increased becoming $57 \quad(83 \%)$ respondents.

Massaging is a fun way to help to strengthen the bond between mother and child. This is the key to baby's development. Touch therapy can stimulate motoric muscles. The development of the baby's brain is divided into three parts: physical aspects, emotional aspects, and cognitive aspects. The physical aspects of a child's brain development affect the body's balance and coordination. Physical aspects are trained with daily routines carried out by children. Mothers can optimize children's brain development by doing stimulation.

Infancy is a golden period as well as a critical period of one's development. It is said to be a critical period because at this time the baby is very sensitive to the environment and is said to be the golden age because the baby's period lasts very short and cannot be repeated. Infancy according to the Ministry of Health is 
divided into two periods, namely the neonatal period and the post neonatal period. The neonatal period starts from the age of 0 to 28 days, while the post neonatal period starts from the age of 29 days to 11 months. Babies are weak individuals and need an adaptation process. The difficulty of the adaptation process will cause the baby to experience weight loss, developmental delay, irregular behavior and even death (Sulung \& Gayatri, 2015).

The results of the research (Niemi, 2017) showed Most studies evaluating the effect of massage in weight gain in premature infants suggest a positive effect on weight gain. Increase in vagal tone has been reported in infants who receive massage and has been suggested as a possible mechanism for improved weight gain. More studies are needed on the underlying mechanisms of the effects of massage therapy on weight gain in preterm infants. While some trials suggest improvements in developmental scores, decreased stress behavior, positive effects on immune system, improved pain tolerance and earlier discharge from the hospital, the number of such studies are small, and further evidence is needed. Further studies, including randomized controlled trials, are needed on the effects of massage in preterm infants.

Babies are individuals who have their own needs so the amount of sleep, wake up, the cry will vary in each baby. During the infant phase, the growth of nerve cells is not perfect so that it takes longer sleep time for nerve development, so that for a maximum body the baby needs sufficient time (Cahyaningrum \& Sulistyorini, 2014).

Babies who get regular touch will be more relaxed and calm. With a smooth circulation of blood and oxygen, the baby's body immunity is better. Not only physically, but body touch also greatly affects emotional, because touch activities will establish bonding between children and parents. Main element of touch therapy is touch, not pressure. Therefore, aside from specialist therapists, baby touch is also good if it is done by mothers or fathers (Utami, 2009).

3. Analyzing the effect of infants touch (Touch therapy) on the nutritional status and development in Gayaman Village Mojokerto Regency.

Based on table 3 it was shown that $\rho=0.003$. This showed that there was an effect of infants touch on the nutritional status. Based on table 4 it was shown that $\rho=$ 0.008 . This showed that there was an effect of infants touch on the development.

The results of the research (Zargham-Boroujeni, Elsagh, \& Mohammadizadeh, 2017) showed The lowest mean pain score recorded in the massage group (0.92) whereas it was 4.84 in the breastfeeding group and 6.16 in the control group. ANOVA test and post-hoc statistics revealed that both interventions resulted in a significant reduction of the pain scores.

Touch therapy does help babies feel calmer because touch therapy movements can help reduce the level of the hormone cortisol, known as stress hormones in the body, and encourage the production of hormones that make the baby feel comfortable. This makes the baby feel touch as a positive experience, so it stimulates the part of the baby's brain that regulates his emotions. When they grow up, this stimulation will help them respond to their situation more positively and adapt more easily to the new environment. 
Also, touch therapy also increases baby alertness and the baby's ability to learn. Babies have $150 \%$ more brain cells than adults. As they grow older, the baby's body begins to 'throw away' the unused brain cells. So, when a baby gets stimulation from touch therapy, especially early on, the baby's brain receives information and is more responsive to learning new things. In other words, touch therapy helps babies to be better prepared to receive stimulation from their environment and learn something from the stimulation. The perceived touch sensation of a touch therapy movement also helps create more dense and comprehensive brain cells.

Touch is the first senses where the baby can react. Touch is also a way for mothers to convey affection to babies. Begin touch as early as possible, the sooner the mother gets physical contact with the child, the sooner the mother's doubts will disappear (Prasetyono, 2009).

Willingness is an impulse in a human who is higher in level than instinct, reflex, and desire. Willingness occurs through a process that is not simple, because the will is based or occurs because of a strong impulse from within human beings (Notoadmodjo, 2010$)$.

The lack of mother's will greatly influence the implementation of touch therapy, which implement of touch therapy done incorrectly because the mother is still afraid to touch her child.

The first factor that affects a person's behavior is age. The age of the respondents is quite mature, but because the age is a productive age, both for work and household activities causes the respondents to have limited time to carry out touch therapy. The second factor that affects mothers in doing touch therapy is education.
According to Kuncoroningrat (1997) cited by Nursalam and pariani, 2001, the higher a person's education, the easier he is to receive information so that more knowledge is also possessed. Conversely, less education will hinder the development of one's attitude to wards newly introduced values. One's education factor determines anxiety, clients with high education will be more able to deal with problems effectively than someone with low education. This shows that education will affect a person's behavior, especially a person's behavior in lifestyle in motivating to participate in health development. The third factor that influences mothers in carrying out touch therapy is work (Abidah, 2012).

According to Loawrence Green, quoted by Notoatmodjo (2007), behaviors that arise with the information obtained from intermediaries encourage or inspire someone to do something (Notoatmodjo, 2007).

This research was supported by research conducted by Nugrohowati and Nurhidayati, (2015) in Margodadi Village, Seyegan Subdistrict, Sleman Regency, the results of the analysis showed that there was a significant effect of touch therapy on growth before and after treatment (Nugrohowati \& Nurhidayati, 2015).

Based on the research of Kulsum, (2014) touch carried out regularly on the legs, abdomen, chest, hands, back, and stretching movements can increase the baby's weight. The touch will make the potential for nerve action happen that stimulates the vagus nerve and will stimulate increased intestinal peristaltic, so that the absorption of food in the body will be more maximal. Touch on babies can also improve blood circulation and increase cell metabolism, so that baby's weight will 
increase which has a positive effect on baby's development (Kulsum, Mediani, \& Bangun, 2017).

\section{CONCLUSION AND SUGGESTIONS}

There is an increase in nutritional status and development of infants after being given a touch therapy.

Based on the results of the research proposed several suggestions, among others: 1) Parents are expected to provide touch to their children not only in their spare time but also as a necessity for parents to provide touch therapy. 2) The next researcher is expected to research on the effect of touch therapy on various aspects so that the benefits of touch therapy can be found more broadly.

\section{REFERENCES}

Abidah, J. D. P. N. (2012). Tingkat Pengetahuan Ibu Tentang Alat Permainan Edukatif untuk perkembangan anak usia pra sekolah (3-5 tahun)(studi kasus di tk. islam pandansari) SURABAYA. Jurnal Dinamika Kebidanan, 2(2).

Cahyaningrum, C., \& Sulistyorini, E. (2014). Hubungan pijat bayi terhadap kualitas tidur bayi umur 0-3 bulan di rb suko asih sukoharjo tahun 2013. Jurnal Kebidanan Indonesia: Journal of Indonesia Midwifery, 5(2).

Chong, K. W., Wright, K., Goh, A., Meyer, R., \& Rao, R. (2018). Growth of children with food allergies in Singapore. Asia Pacific Allergy, 8(4), e34-e34.

https://doi.org/10.5415/apallergy.2018 $.8 . e 34$

Gao, L., Jia, C., \& Huang, H. (2018). Paediatric massage for treatment of acute diarrhoea in children: a metaanalysis. BMC Complementary and Alternative Medicine, 18(1), 257. https://doi.org/10.1186/s12906-0182324-4

Hanifah, L. (2015). Pengaruh lama pendidikan, jenis pekerjaan, usia kawin pertama dan penggunaan alat kontrasepsi terhadap jumlah anak yang dilahirkan wanita pasangan usia subur (pus) di desa merak batin kecamatan natar kabupaten lampung selatan tahun 2014. Fakultas Keguruan dan Ilmu Pendidikan.

Irva, T. S., Hasanah, O., \& Woferst, R. (2014). Pengaruh terapi pijat terhadap peningkatan Berat badan bayi. Jurnal Online Mahasiswa Program Studi Ilmu Keperawatan Universitas Riau, 1(2), 1-9.

Kesehatan, K., \& Penelitian, B. (2014). Laporan Nasional Riset Kesehatan Dasar (RISKESDAS) 2013. Jakarta: Balitbangkes Kemenkes RI.

Kulsum, D. U., Mediani, H. S., \& Bangun, A. V. (2017). Pengaruh Swedish Massage Therapy terhadap Tingkat Kualitas Hidup Penderita Leukemia Usia Sekolah. Jurnal Keperawatan Padjadjaran, 5(2).

Nasional, B. P. P. (2015). Laporan Tahunan MDGs 2014. Jakarta. Bappenas.

Niemi, A.-K. (2017). Review of Randomized Controlled Trials of Massage in Preterm Infants. Children, 4(4), 21. https://doi.org/10.3390/children40400 21

Notoadmodjo, S. (2010). Promosi Kesehatan Teori \& Perilaku. Jakarta: Rineka Cipta. 
Notoatmodjo, S. (2007). Promosi kesehatan dan ilmu perilaku. Jakarta: Rineka Cipta, 20.

Nugrohowati, R., \& Nurhidayati, E. (2015). Pengaruh Pijat Bayi terhadap Tumbuh Kembang Bayi Usia 0-12 Bulan di Desa Margodadi Kecamatan Seyegan Kabupaten Sleman. STIKES'Aisyiyah Yogyakarta.

Nursalam, D. K., \& Dian, N. (2007). Asuhan keperawatan pada pasien terinfeksi HIV. Jakarta: Salemba Medika.

Potter, P. A., \& Perry, A. G. (2005). Buku ajar fundamental keperawatan: konsep, proses, dan praktik. Jakarta: $E g c, 1$.

Prasetyono, D. S. (2009). Buku pintar ASI eksklusif. Yogyakarta: DIVA.

Rochjati, P. (2003). Skrining antenatal pada ibu hamil. Surabaya: FK UNAIR.

Soetjiningsih, D. (1995). Tumbuh kembang anak. Jakarta: Penerbit Buku Kedokteran EGC, 1, 995.

Sulung, N., \& Gayatri, A. C. D. (2015). Efektivitas Massage Baby Terhadap Peningkatan Berat Badan Bayi Usia 34 Bulan di BPS BUNDA Kecamatan Mandiangin Koto Selayan Bukittinggi Tahun 2014. Menara Ilmu, IX.

Utami, R. (2009). Pedoman Pijat Bayi. PT Trubus Agri Widia: Jakarta.

Zargham-Boroujeni, A., Elsagh, A., \& Mohammadizadeh, M. (2017). The Effects of Massage and Breastfeeding on Response to Venipuncture Pain among Hospitalized Neonates. Iranian Journal of Nursing and Midwifery Research, 22(4), 308-312. https://doi.org/10.4103/ijnmr.IJNMR_ 119_13 